\title{
A three year follow up of patients allocated to placebo, or oral or injectable gold therapy for rheumatoid arthritis
}

\author{
H A CAPELL, D LEWIS, AND J CAREY \\ From the Centre for Rheumatic Diseases, Royal Infirmary, Glasgow
}

SUMMARY Ninety patients randomly allocated to receive auranofin, matching placebo, or sodium aurothiomalate have been followed up for three years. Inefficacy led to cessation of treatment in 14 patients receiving auranofin, 27 receiving placebo, and one receiving sodium aurothiomalate. Twenty seven of the patients receiving placebo were reallocated within the study and 16 continued therapy at three years. This group showed similar statistically significant improvement in clinical and laboratory parameters at one, two, and three years to those on an active drug from the outset. Patients who discontinued auranofin because of inefficacy were offered sodium aurothiomalate therapy-eight patients in this group completed three years of treatment on sodium aurothiomalate and showed significant improvement in some but not all parameters. A hand radiograph erosion score showed a deterioration in $80 \%$ of patients remaining on auranofin, $75 \%$ of those on sodium aurothiomalate, and $80 \%$ of the original placebo group who continued an active drug for three years. Although more patients discontinued auranofin over the study period because of inefficacy, no difference could be shown between the degree of improvement in the subgroup who remained on auranofin and those receiving sodium aurothiomalate. No disadvantage in outcome could be shown for patients originally assigned to placebo.

Key words: auranofin, sodium aurothiomalate.

It has been suggested that auranofin is less toxic than sodium aurothiomalate, ${ }^{1}$ but controlled data about efficacy are needed to evaluate the role of this oral gold preparation in the management of rheumatoid arthritis. In addition, since long term therapy with a second line agent is necessary to demonstrate sustained benefit it is vital to continue with studies over several years, even when a drug has been shown to be effective in the short term. ${ }^{2}$ Of equal importance is prolonged meticulous monitoring to detect possible late toxicity.

The use of a placebo group in any study poses ethical problems and there is a need for careful follow up of patients originally assigned to placebo to ensure that no adverse outcome is apparent. This study was begun in 1980 and six month and one year results have previously been published. ${ }^{34}$ This

Accepted for publication 7 April 1986.

Correspondence to $\mathrm{Dr} H$ A Capell, Centre for Rheumatic Diseases, Royal Infirmary, Glasgow G4 OSF. report deals with a minimum of three years of follow up of patients receiving either sodium aurothiomalate or auranofin, or alternatively a minimum of three years after patients changed from placebo to one of these two active drugs. Data are also available on patients who discontinued auranofin and were reassigned to sodium aurothiomalate.

\section{Patients and methods}

Ninety patients with definite or classical rheumatoid arthritis $^{5}$ were enrolled in the study. No patient was receiving corticosteroids or had received these drugs for three months before the study, and similarly none had received another second line agent in the three months before the study. All continued nonsteroidal anti-inflamatory drugs, as necessary, throughout. All had active disease which required the addition of second line therapy because of failure to respond sufficiently to non-steroidal antiinflammatory drugs alone. 


\section{TREATMENT ALLOCATION}

Patients were randomly allocated to receive auranofin, matching placebo, or injectable sodium aurothiomalate (30 in each group). The sodium aurothiomalate treatment regimen consisted of a 10 $\mathrm{mg}$ test dose and $50 \mathrm{mg}$ weekly until response, at which time the injections were spaced out to fortnightly, three weekly, and ultimately four weekly. Thirty patients received auranofin in a dose of 3 mg twice daily, and 30 received auranofin placebo which was identical in appearance to auranofin and given in a similar dose of one tablet twice daily. When patients discontinued the initial therapy they were offered a further allocation within the study if it was thought safe and appropriate. Patients were encouraged to continue therapy for 24 weeks unless side effects supervened. Thereafter, if they felt they had failed to derive benefit from their medication an alternative was offered. Of the 30 patients initally allocated to placebo, all had discontinued therapy by 36 weeks because of lack of effect; 27 were randomly reallocated to receive either sodium aurothiomalate or auranofin. Ten of these 27 patients went on to receive sodium aurothiomalate, and 17 auranofin. Formal analysis in this study is restricted to the patients who either received sodium aurothiomalate or auranofin first, or immediately after placebo. It was considered of interest to transfer patients who failed on auranofin to sodium aurothiomalate, but these patients cannot be included in the total treatment group since they represent a poor prognostic group and would bias the study: they are therefore analysed separately.

The standard clinical and laboratory measurements of efficacy were performed, and $x$ rays of hands were analysed by modification of the Sharp method $^{6}$ at the start of the study and one and three years later.

Statistical analysis was by non-parametric tests. ${ }^{7}$

\section{Results}

Retrospective analysis of the initial Mallya and Mace index ${ }^{8}$ in the 90 patients shows that none had $\underset{\overrightarrow{9}}{\overrightarrow{7}}$ mild disease, i.e., grade 1, 14 were in grade 2, 70 in grade 3 , and six in grade 4 .

At three years $17(57 \%)$ of the 30 patients originally allocated to sodium aurothiomalate remained on treatment compared with seven $(23 \%)$ allocated to auranofin. All the placebo patients had discontinued therapy before one year (the figures. for sodium aurothiomalate and auranofin at that $\overrightarrow{\vec{\omega}}$ stage were: 22 of $30(73 \%)$ remained on sodium $\stackrel{\omega}{\omega}$ aurothiomalate, 17 of $30(57 \%)$ remained on auranofin.) A summary of the reasons for discontinuation of therapy in the three treatment groups by of original allocation is shown in Table 1 . Overall, adverse reactions were the most common reason for $O$ discontinuation of sodium aurothiomalate (nine $\circ$ patients), whereas inefficacy was the most common reason for discontinuation of auranofin (14 pa- $c s$ tients).

Of the 10 patients who received sodium auro- $\frac{\Phi}{\Phi}$ thiomalate after placebo, four were still on therapy at three years. Of the 17 patients who received $\stackrel{\mathbb{}}{-}$ auranofin after placebo, nine remained की $\vec{\varphi}$ treatment at three years. Efficacy has been assess on both the 17 of 30 and 21 (i.e., 17+4) of 40 (i.e.; $30+10)$ patients receiving sodium aurothiomalate, and the seven of 30 and 16 (i.e. 7+9) of 47 (i.e., $30+17)$ auranofin patients. The median and range of clinical and laboratory parameters and the p values $\stackrel{\mathscr{Q}}{\mathbb{Q}}$ of the Wilcoxon matched pairs signed ranks test comparing initial values with those at one, two, and three years for sodium aurothiomalate and auranofin are shown in Appendices 1 and 2. In the sodium aurothiomalate groups all the parameters except grip strength changed significantly and remained improved over the three years; in the auranofin

Table 1 Outcome over three years by original treatment allocation

\begin{tabular}{|c|c|c|c|c|c|c|}
\hline & \multicolumn{2}{|c|}{ Placebo } & \multicolumn{2}{|c|}{ Sodium aurothiomalate } & \multicolumn{2}{|c|}{ Auranofin } \\
\hline & $n$ & $\%$ & $n$ & $\%$ & $n$ & $\%$ \\
\hline Adverse event & 2 & 7 & 9 & 30 & 5 & 17 \\
\hline Inefficacy & 27 & 90 & 1 & 3 & 14 & 47 \\
\hline Intercurrent illness & 1 & 3 & 1 & 3 & 3 & 10 \\
\hline Non-compliance & 0 & 0 & $2^{*}$ & 7 & $1 * *$ & 3 \\
\hline Total who discontinued therapy & 30 & 100 & 13 & 43 & 23 & 77 \\
\hline Total on original therapy & 0 & 0 & 17 & 57 & 7 & 23 \\
\hline
\end{tabular}

${ }^{*}$ Remission; ${ }^{* *}$ moved 
group all the parameters except grip strength and haemoglobin improved and all except the erythrocyte sedimentation rate (ESR) remained significantly better at three years. In addition, the group originally assigned to placebo, who then went on to either sodium aurothiomalate or auranofin and who reached three years of therapy $(n=16)$, are shown in Appendix 3. This group also improved significantly over the three year period. Of the 14 patients who stopped auranofin because of inefficacy and went on to sodium aurothiomalate, five were still on sodium aurothiomalate and responding at three years. In addition, a further five patients received sodium aurothiomalate after both placebo and auranofin had failed; three of these five were still receiving sodium aurothiomalate therapy at the end of three years. Thus a total of eight of the patients who were considered to have a poor prognosis in that they had failed to respond to auranofin were still receiving sodium aurothiomalate treatment at three years; response in this group is shown in Appendix 4. Although many parameters improved significantly, the response was not as good as that seen in the original sodium aurothiomalate group or in those who received sodium aurothiomalate after placebo.

In addition, one patient who received sodium aurothiomalate for more than a year and had responded well but developed a rash was changed to auranofin; the rash did not recur and she continued therapy for three years, with good response.
Table 2 Adverse effects leading to withdrawal of therapy: three year follow up

\begin{tabular}{lll}
\hline & $\begin{array}{l}\text { Sodium } \\
\text { aurothiomalate } \\
(n)\end{array}$ & $\begin{array}{l}\text { Auranofin } \\
(n)\end{array}$ \\
\hline Rash & 6 & 1 \\
$\begin{array}{l}\text { Nitritoid reaction } \\
\text { Cholestatic jaundice }\end{array}$ & 1 & - \\
$\begin{array}{l}\text { Diarrhoea } \\
\text { Leucopenia }\end{array}$ & 1 & - \\
Proteinuria & - & 1 \\
Haematuria & 1 & - \\
Total & - & 1 \\
\hline
\end{tabular}

Original allocation 30 in each group.

Table 3 Treatment outcome at three years in the original three groups

\begin{tabular}{lccc}
\hline & Placebo & $\begin{array}{l}\text { Sodium } \\
\text { auro- } \\
\text { thiomalate }\end{array}$ & Auranofin \\
\hline Still receiving auranofin & 9 & 1 & 7 \\
$\begin{array}{l}\text { Still receiving sodium } \\
\quad \text { aurothiomalate }\end{array}$ & 7 & 17 & 5 \\
$\begin{array}{l}\text { Alternative second line drug } \\
\text { No further second line drug }\end{array}$ & 2 & 8 & 13 \\
Not attending the Centre for & 0 & 1 & 2 \\
$\quad$ Rheumatic Diseases & 0 & 1 & 1 \\
Died & 2 & 2 & 2 \\
Total & 30 & 30 & 30 \\
\hline
\end{tabular}

Thus $6 / 90$ died during the three year follow up; $82 / 84$ surviving patients still attend the Centre for Rheumatic Diseases; and 77/82 are still on second line therapy.

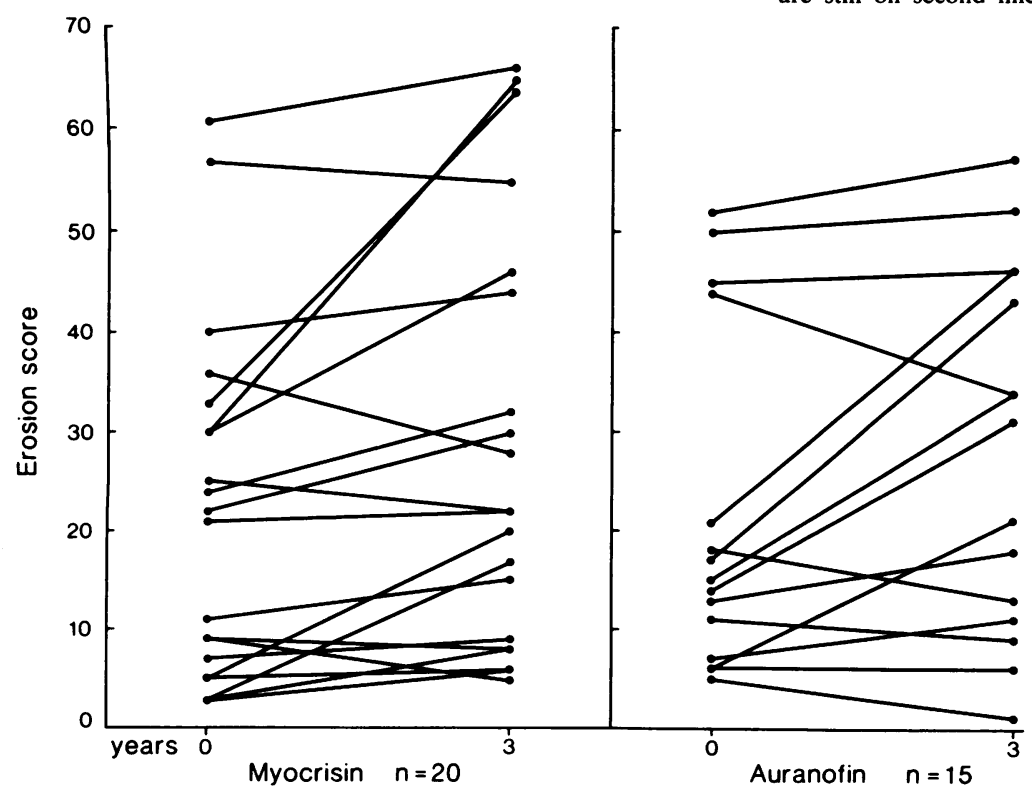

Fig. 1 Changes in erosion score on hand $x$ ray (modified Sharp method) in sodium aurothiomalate (Myocrisin) and auranofin groups. 
Table 4 Changes in clinical and laboratory parameters in two patients who showed marked radiological progression, and one patient who showed little change over three years of sodium aurothiomalate therapy

\begin{tabular}{|c|c|c|c|c|c|c|c|c|c|c|c|c|}
\hline & \multicolumn{4}{|c|}{ Patient 1} & \multicolumn{4}{|c|}{ Patient 2} & \multicolumn{4}{|c|}{ Patient 3} \\
\hline & 0 & 1 year & 2 years & 3 years & 0 & 1 year & 2 years & 3 years & 0 & 1 year & 2 years & 3 years \\
\hline Pain $(\mathrm{mm})^{*}$ & 40 & 37 & 18 & 20 & 60 & 0 & 0 & 0 & ND & 0 & 1 & 1 \\
\hline Grip (mmHg) & 64 & 79 & 76 & 86 & 107 & 116 & 118 & 118 & 67 & 71 & 71 & 75 \\
\hline $\mathrm{Hb}(\mathrm{g} / \mathrm{dl})^{\dagger}$ & $11 \cdot 0$ & $12 \cdot 3$ & $12 \cdot 4$ & $12 \cdot 4$ & $11 \cdot 4$ & $12 \cdot 8$ & $13 \cdot 2$ & $13 \cdot 8$ & $11 \cdot 4$ & $11 \cdot 1$ & $10 \cdot 5$ & $12 \cdot 8$ \\
\hline $\operatorname{ESR}(\mathrm{mm} / 1 \mathrm{st} \mathrm{h})$ & 65 & 18 & 16 & 15 & 38 & 11 & 4 & 6 & 91 & 86 & 59 & 33 \\
\hline CRP $(\mathrm{mg} / \mathrm{l})^{\ddagger}$ & 40 & 37 & - & - & 41 & 10 & - & - & 13 & 10 & - & - \\
\hline Erosion score & 30 & 46 & - & 68 & 30 & 37 & - & 46 & 57 & 63 & - & 55 \\
\hline
\end{tabular}

*Visual analogue-10 $\mathrm{cm}$ scale.

${ }^{\dagger} \mathrm{SI}$ conversion: $\mathrm{g} / \mathrm{dl} \times \mathbf{1 0}=\mathrm{g} / \mathrm{l}$.

${ }^{\ddagger} \mathrm{CRP}=\mathrm{C}$ reactive protein.

\section{TOXICITY}

A summary of adverse events leading to withdrawal of therapy in the two treatment groups is shown in Table 2. One auranofin patient developed a sudden dramatic fall in white cell count after five weeks of therapy; he remained in remission throughout the three year period of follow up despite receiving no further second line drug, and required only minimal doses of non-steroidal anti-inflammatory drugs intermittently. All patients who developed diarrhoea on auranofin recovered completely on stopping therapy. No sustained toxicity was demonstrated with either drug.

The total treatment outcome over the three years by original treatment allocation is shown in Table 3 . Six patients died during the three year follow up, two in each group. The causes appeared unrelated to therapy, though one patient originally allocated to sodium aurothiomalate was withdrawn from the study at 12 weeks because of cervical cord disease and the need for surgery, and active rheumatoid arthritis and vasculitis were largely responsible for his death. Of the 84 surviving patients, 82 still attend this centre; of the two who do not attend, one has moved and could not continue auranofin because supplies were not available at the time in the new area; the other (receiving sodium aurothiomalate) had gone into remission and had not felt it necessary to continue to attend a specialist clinic. The other sodium aurothiomalate patient who had received no further second line therapy but was still attending this centre had also gone into remission initially and had wished to stop therapy in order to try and fall pregnant; she has not, however, succeeded in doing so and is now being assessed for penicillamine therapy. Of the 82 patients still attending this centre, 77 are either on their original second line therapy or have had an alternative second line drug during the three year follow up period.
At the end of three years, of the 30 patients originally allocated to placebo, nine were stillo

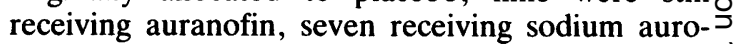
thiomalate, 10 had received alternative second line $\overrightarrow{c s}$ drugs, and two had died, one of whom had in the $\frac{}{8}$ interim received a second line agent. Thus out of the $\overrightarrow{\mathbb{D}}$ 30 , a total of 29 went on to receive a second line 3 drug and their outcome was similar to those who received sodium aurothiomalate or auranofin in the $\vec{\theta}$ first instance.

\section{RA D I O L OG Y}

Films at 0 and 3 years were available in 20 patients receiving sodium aurothiomalate and 15 receiving auranofin. The erosion scores on hand $x$ ray for theseo

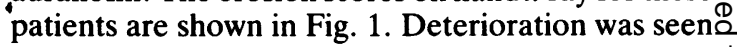
in 15 patients in the sodium aurothiomalate group, $\overrightarrow{\overrightarrow{0}}$ with four showing improvement and one no change. 3 The median and range for the scores at 0 and 3 years were $22(3-61)$ and $25(5-69)$ respectively. In the auranofin patients 12 deteriorated, one improved, and two showed no change. The median and range? at 0 and 3 years were $15(5-52)$ and $31(1-57) \frac{3}{3}$ respectively. Both groups showed significant deterioration (Wilcoxon), and reduction of the ESR to을 less than $30 \mathrm{~mm} / 1 \mathrm{st} h$ did not protect against progression of $x$ ray change. Overall, only five patients in each group showed marked deteriora- $\rightarrow$ tion. No correlation with any clinical variable could be shown. Details of the clinical and laboratory scores versus erosions for two patients who deterio-rated most markedly, and one who improved, while 0 receiving sodium aurothiomalate are shown inc Table 4.

\section{Discussion}

It is reassuring to note that the patients who were allocated to placebo within the study fared no worse 0 than those who received an active drug from the $\underset{\vec{D}}{\vec{D}}$ 
outset. It is true that the placebo group experienced a period of some months without beneficial effect, but this also occurred in 14 patients who received auranofin in the first instance. Thus if patients are meticulously followed up and all those who have received placebo are offered an active second line drug it would seem ethical to include such a group as necessary. It is of interest that this placebo group was clearly capable of showing a response to an active drug but that spontaneous improvement in placebo patients or indeed in the other patients who discontinued the active agents because of inefficacy or toxicity was not seen.

Overall, sodium aurothiomalate appears to be a more effective agent in the treatment of rheumatoid arthritis than auranofin, and the proportion of patients discontinuing the drug because of inefficacy. is much higher with auranofin. The group of patients who found auranofin ineffective but then showed a response to sodium aurothiomalate lends further weight to the impression that auranofin is not such a powerful second line agent as injectable gold, but the numbers in this study are insufficient to test this hypothesis statistically. Nevertheless, a subgroup of patients treated with auranofin achieved a response very similar to that of a group treated with sodium aurothiomalate, and the toxicity was somewhat lower. Unfortunately, auranofin is not free of haematological side effects and this means that monitoring needs to be continuous with either drug. Thus the original hopes of a much safer form of gold have not been realised.

Radiological deterioration was seen in most patients over three years. Unfortunately, insufficient one year films were available to allow comment on possible slowing of progression after the first year of therapy (allowing for the expected deterioration in the initial months of treatment). This is a fault which cannot be rectified at this stage but is highly relevant to future study design. Other workers who have maintained more patients on placebo over one year have suggested that auranofin produces a slowing in radiological progression in rheumatoid arthritis. ${ }^{9}$

It is worthy of note that patients with severe rheumatoid arthritis such as those involved in this study continue to need active therapy over many years. When treating a disease such as rheumatoid arthritis it would appear that only those patients who die or emigrate are lost to the rheumatologist's load. The extent to which auranofin will lighten that load is unclear: this study suggests that beneficial effects will be demonstrable in a proportion of patients with rheumatoid arthritis but that careful monitoring remains mandatory.

\section{Apendix 1}

Table Median (range) and p values (Wilcoxon) for patients receiving sodium aurothiomalate or auranofin first over one, two, and three years

\begin{tabular}{|c|c|c|c|c|c|c|c|c|}
\hline & \multicolumn{4}{|c|}{ Sodium aurothiomalate first $(n=17)$} & \multicolumn{4}{|c|}{ Auranofin first $(n=7)$} \\
\hline & 0 & 1 year & 2 years & 3 years & 0 & 1 year & 2 years & 3 years \\
\hline Articular index & $\begin{array}{l}10 \\
(6-40)\end{array}$ & $\begin{array}{l}5 \\
(0-37) \\
0 \cdot 016\end{array}$ & $\begin{array}{l}4 \cdot 5 \\
(0-25) \\
0 \cdot 003\end{array}$ & $\begin{array}{l}5 \cdot 5 \\
(0-21) \\
0 \cdot 012\end{array}$ & $\begin{array}{l}14 \\
(11-17)\end{array}$ & $\begin{array}{l}5 \\
(0-12) \\
0 \cdot 028\end{array}$ & $\begin{array}{l}4 \cdot 1 \\
(0-12) \\
0 \cdot 028\end{array}$ & $\begin{array}{l}7 \cdot 5 \\
(3-10) \\
0 \cdot 028\end{array}$ \\
\hline Grip (mmHg) & $\begin{array}{l}108 \\
(55-358)\end{array}$ & $\begin{array}{l}115 \\
(58-300) \\
0 \cdot 313\end{array}$ & $\begin{array}{l}100 \\
(65-300) \\
0 \cdot 569\end{array}$ & $\begin{array}{l}102 \\
(57-300) \\
0 \cdot 642\end{array}$ & $\begin{array}{l}99 \\
(60-253)\end{array}$ & $\begin{array}{l}128 \\
(60-300) \\
0 \cdot 043\end{array}$ & $\begin{array}{l}103 \\
(55-300) \\
0 \cdot 142\end{array}$ & $\begin{array}{l}99 \\
(47-240) \\
0.917\end{array}$ \\
\hline Morning stiffness (h) & $\begin{array}{l}1 \cdot 16 \\
(0-4 \cdot 00)\end{array}$ & $\begin{array}{l}0 \cdot 46 \\
(0-2 \cdot 4) \\
0 \cdot 041\end{array}$ & $\begin{array}{l}0.48 \\
(0-2 \cdot 4) \\
0 \cdot 013\end{array}$ & $\begin{array}{l}0 \cdot 38 \\
(0-1 \cdot 5) \\
0 \cdot 011\end{array}$ & $\begin{array}{l}1 \cdot 83 \\
(0 \cdot 6-2 \cdot 5)\end{array}$ & $\begin{array}{l}0 \cdot 50 \\
(0-1 \cdot 5) \\
0 \cdot 028\end{array}$ & $\begin{array}{l}0 \cdot 4 \\
(0-1 \cdot 0) \\
0 \cdot 028\end{array}$ & $\begin{array}{l}0 \cdot 5 \\
(0-1 \cdot 0) \\
0 \cdot 028\end{array}$ \\
\hline $\mathrm{Hb}(\mathrm{g} / \mathrm{dl})^{*}$ & $\begin{array}{l}11 \cdot 3 \\
(9 \cdot 2-15 \cdot 4)\end{array}$ & $\begin{array}{l}12 \cdot 6 \\
(9 \cdot 7-15 \cdot 4) \\
0 \cdot 028\end{array}$ & $\begin{array}{l}12 \cdot 4 \\
(9 \cdot 7-15 \cdot 7) \\
0 \cdot 052\end{array}$ & $\begin{array}{l}12 \cdot 6 \\
(9 \cdot 0-15 \cdot 7) \\
0 \cdot 009\end{array}$ & $\begin{array}{l}12 \cdot 6 \\
(10 \cdot 4-15 \cdot 3)\end{array}$ & $\begin{array}{l}12 \cdot 2 \\
(10 \cdot 4-15 \cdot 4) \\
0 \cdot 866\end{array}$ & $\begin{array}{l}12 \cdot 5 \\
(10 \cdot 6-15 \cdot 5) \\
0 \cdot 398\end{array}$ & $\begin{array}{l}12 \cdot 6 \\
(10 \cdot 8-15 \cdot 2) \\
0 \cdot 345\end{array}$ \\
\hline $\operatorname{ESR}(\mathrm{mm} / 1 \mathrm{st} \mathrm{h})$ & $\begin{array}{l}55 \\
(4-102)\end{array}$ & $\begin{array}{l}23 \\
(1-86) \\
0 \cdot 0001\end{array}$ & $\begin{array}{l}16 \\
(1-68) \\
0 \cdot 001\end{array}$ & $\begin{array}{l}15 \\
(1-46) \\
0 \cdot 0001\end{array}$ & $\begin{array}{l}50 \\
(8-81)\end{array}$ & $\begin{array}{l}19 \\
(2-52) \\
0 \cdot 018\end{array}$ & $\begin{array}{l}16 \\
(3-59) \\
0 \cdot 063\end{array}$ & $\begin{array}{l}17 \\
(1-58) \\
0.052\end{array}$ \\
\hline Platelets $\times 10^{-9} / 1$ & $\begin{array}{l}402 \\
(282-651)\end{array}$ & $\begin{array}{l}345 \\
(196-507) \\
0 \cdot 004\end{array}$ & $\begin{array}{l}318 \\
(206-470) \\
0 \cdot 001\end{array}$ & $\begin{array}{l}326 \\
(222-641) \\
0 \cdot 001\end{array}$ & $\begin{array}{l}487 \\
(181-653)\end{array}$ & $\begin{array}{l}303 \\
(170-521) \\
0 \cdot 018\end{array}$ & $\begin{array}{l}302 \\
(198-429) \\
0 \cdot 028\end{array}$ & $\begin{array}{l}365 \\
(172-505) \\
0 \cdot 063\end{array}$ \\
\hline
\end{tabular}

*SI conversion: $\mathrm{g} / \mathrm{dl} \times 10=\mathrm{g} / \mathrm{l}$. 
710 Capell, Lewis, Carey

Appendix 2

Table Median (range) and p values (Wilcoxon) matched pairs signed rank test for patients receiving sodium aurothiomalate or auranofin first or after placebo

\begin{tabular}{|c|c|c|c|c|c|c|c|c|}
\hline & \multicolumn{4}{|c|}{ Sodium aurothiomalate first and after placebo $(n=21)$} & \multicolumn{4}{|c|}{ Auranofin first and after placebo $(n=16)$} \\
\hline & 0 & 1 year & 2 years & 3 years & 0 & 1 year & 2 years & 3 years \\
\hline Articular index & $\begin{array}{l}10 \cdot 5 \\
(6-42)\end{array}$ & $\begin{array}{l}9 \cdot 8 \\
(0-37) \\
0 \cdot 011\end{array}$ & $\begin{array}{l}8 \cdot 5 \\
(0-26) \\
0 \cdot 002\end{array}$ & $\begin{array}{l}8 \\
(0-23) \\
0 \cdot 009\end{array}$ & $\begin{array}{l}17 \cdot 2 \\
(0-55)\end{array}$ & $\begin{array}{l}7 \\
(0-35) \\
0 \cdot 001\end{array}$ & $\begin{array}{l}8 \\
(0-36) \\
0 \cdot 001\end{array}$ & $\begin{array}{l}9 \cdot 7 \\
(3-23) \\
0 \cdot 002\end{array}$ \\
\hline Grip (mmHg) & $\begin{array}{l}108 \\
(55-358)\end{array}$ & $\begin{array}{l}117 \\
(57-300) \\
0 \cdot 263\end{array}$ & $\begin{array}{l}118 \\
(65-300) \\
0 \cdot 305\end{array}$ & $\begin{array}{l}106 \\
(54-300) \\
0 \cdot 421\end{array}$ & $\begin{array}{l}93 \\
(48-253)\end{array}$ & $\begin{array}{l}105 \\
(60-300) \\
0 \cdot 162\end{array}$ & $\begin{array}{l}94 \\
(54-300) \\
0 \cdot 211\end{array}$ & $\begin{array}{l}98 \\
(47-240) \\
0 \cdot 307\end{array}$ \\
\hline $\begin{array}{c}\text { Morning stiffness (h) } \\
\text { p }\end{array}$ & $\begin{array}{l}1 \cdot 13 \\
(0-24)\end{array}$ & $\begin{array}{l}0 \cdot 60 \\
(0-24) \\
0 \cdot 10\end{array}$ & $\begin{array}{l}0 \cdot 5 \\
(0-24) \\
0 \cdot 002\end{array}$ & $\begin{array}{l}0.437 \\
(0-1 \cdot 5) \\
0 \cdot 004\end{array}$ & $\begin{array}{l}1 \cdot 66 \\
(1 \cdot 0-24)\end{array}$ & $\begin{array}{l}0.96 \\
(0-24) \\
0 \cdot 028\end{array}$ & $\begin{array}{l}0 \cdot 54 \\
(0-4) \\
0 \cdot 005\end{array}$ & $\begin{array}{l}0 \cdot 75 \\
(0-2) \\
0 \cdot 002\end{array}$ \\
\hline $\mathrm{Hb}(\mathrm{g} / \mathrm{dl})^{*}$ & $\begin{array}{l}11 \cdot 3 \\
(9 \cdot 2-15 \cdot 9)\end{array}$ & $\begin{array}{l}12 \cdot 8 \\
(9 \cdot 7-15 \cdot 9) \\
0 \cdot 005\end{array}$ & $\begin{array}{l}12 \cdot 4 \\
(9 \cdot 7-17) \\
0 \cdot 011\end{array}$ & $\begin{array}{l}12 \cdot 7 \\
(90-166) \\
0 \cdot 002\end{array}$ & $\begin{array}{l}12 \cdot 8 \\
(10 \cdot 4-15 \cdot 3)\end{array}$ & $\begin{array}{l}13 \cdot 0 \\
(10 \cdot 4-15 \cdot 4) \\
0 \cdot 875\end{array}$ & $\begin{array}{l}12 \cdot 7 \\
(10 \cdot 6-15 \cdot 7) \\
0 \cdot 205\end{array}$ & $\begin{array}{l}12 \cdot 9 \\
(108-163) \\
0.096\end{array}$ \\
\hline $\begin{array}{r}\operatorname{ESR}(\mathrm{mm} / 1 \mathrm{st} \mathrm{h}) \\
\mathrm{p}\end{array}$ & $\begin{array}{l}55 \\
(3-107)\end{array}$ & $\begin{array}{l}18 \\
(1-86) \\
0 \cdot 000\end{array}$ & $\begin{array}{l}16 \\
(1-68) \\
0 \cdot 000\end{array}$ & $\begin{array}{l}15 \\
(1-46) \\
0 \cdot 000\end{array}$ & $\begin{array}{l}45 \cdot 5 \\
(4-90)\end{array}$ & $\begin{array}{l}24 \cdot 5 \\
(2-58) \\
0 \cdot 002\end{array}$ & $\begin{array}{l}17 \cdot 5 \\
(3-105) \\
0 \cdot 036\end{array}$ & $\begin{array}{l}24 \cdot 5 \\
(1-84) \\
0 \cdot 014\end{array}$ \\
\hline Platelets $\times 10^{-9} / 1$ & $\begin{array}{l}402 \\
(235-651)\end{array}$ & $\begin{array}{l}345 \\
(181-507) \\
0.003\end{array}$ & $\begin{array}{l}318 \\
(206-470) \\
0 \cdot 001\end{array}$ & $\begin{array}{l}326 \\
(206-641) \\
0.001\end{array}$ & $\begin{array}{l}383 \\
(181-653)\end{array}$ & $\begin{array}{l}303 \\
(170-521) \\
0 \cdot 030\end{array}$ & $\begin{array}{l}316 \\
(182-471) \\
0 \cdot 019\end{array}$ & $\begin{array}{l}365 \\
(172-505) \\
0 \cdot 109\end{array}$ \\
\hline
\end{tabular}

*SI conversion: $\mathrm{g} / \mathrm{dl} \times 10=\mathrm{g} / 1$.

\section{Appendix 3}

Table Group originally assigned to placebo $(n=16)$ who then went on to receive either sodium aurothiomalate or auranofin and reached three years of therapy

\begin{tabular}{|c|c|c|c|c|}
\hline & 0 & 1 year & 2 years & 3 years \\
\hline $\begin{array}{l}\text { Articular } \\
\text { index }\end{array}$ & $\begin{array}{l}32 \\
(0-55)\end{array}$ & $\begin{array}{l}10 \cdot 2 \\
(0-35) \\
0 \cdot 002\end{array}$ & $\begin{array}{l}12 \cdot 0 \\
(0-36) \\
0 \cdot 003\end{array}$ & $\begin{array}{l}14 \cdot 5 \\
(4-23) \\
0 \cdot 005\end{array}$ \\
\hline $\begin{array}{r}\text { Grip } \\
\quad \text { pm }\end{array}$ & $\begin{array}{l}79 \\
(48-160)\end{array}$ & $\begin{array}{l}105 \\
(57-158) \\
0 \cdot 363\end{array}$ & $\begin{array}{l}106 \\
(54-155) \\
0 \cdot 149\end{array}$ & $\begin{array}{l}119 \\
(54-171) \\
0.030\end{array}$ \\
\hline $\begin{array}{c}\text { Morning stiff- } \\
\text { ness (h) } \\
\text { p }\end{array}$ & $\begin{array}{l}3.93 \\
(0.75-24)\end{array}$ & $\begin{array}{l}1.04 \\
(0-24) \\
0.028\end{array}$ & $\begin{array}{l}0.92 \\
(0-4) \\
0.005\end{array}$ & $\begin{array}{l}0.75 \\
(0-2 \cdot 0) \\
0.004\end{array}$ \\
\hline $\begin{array}{r}\mathrm{Hb}(\mathrm{g} / \mathrm{dl})^{*} \\
\mathrm{p}\end{array}$ & $\begin{array}{l}12 \cdot 7 \\
(9 \cdot 1-15 \cdot 9)\end{array}$ & $\begin{array}{l}13 \cdot 3 \\
(10 \cdot 6-15 \cdot 9) \\
0 \cdot 060\end{array}$ & $\begin{array}{l}12 \cdot 9 \\
(11 \cdot 0-17 \cdot 0) \\
0 \cdot 025\end{array}$ & $\begin{array}{l}13 \cdot 0 \\
(10 \cdot 9-16 \cdot 7) \\
0 \cdot 008\end{array}$ \\
\hline $\begin{array}{c}\underset{(\mathrm{mm} / 1 \mathrm{st} h)}{\mathrm{ESR}} \\
\mathrm{p}\end{array}$ & $\begin{array}{l}46 \\
(3-127)\end{array}$ & $\begin{array}{l}24 \\
(7-58) \\
0.005\end{array}$ & $\begin{array}{l}17 \cdot 2 \\
(1-105) \\
0 \cdot 018\end{array}$ & $\begin{array}{l}24 \cdot 5 \\
(1-84) \\
0.006\end{array}$ \\
\hline $\begin{array}{c}\text { Platelets } \times \\
10^{-9} / 1\end{array}$ & $\begin{array}{l}360 \\
(235-618)\end{array}$ & $\begin{array}{l}290 \\
(181-466) \\
0 \cdot 191\end{array}$ & $\begin{array}{l}316 \\
(182-471) \\
0 \cdot 118\end{array}$ & $\begin{array}{l}356 \\
(208-415) \\
0 \cdot 173\end{array}$ \\
\hline
\end{tabular}

*SI conversion: $\mathrm{g} / \mathrm{dl} \times 10=\mathrm{g} / \mathrm{l}$.

\section{Appendix 4}

Table Sodium aurothiomalate after auranofin $(n=8)$

\begin{tabular}{|c|c|c|c|c|}
\hline & 0 & 1 year & 2 years & 3 years \\
\hline $\begin{array}{c}\text { Articular } \\
\text { index }\end{array}$ & $\begin{array}{l}15 \cdot 5 \\
(6-45)\end{array}$ & $\begin{array}{l}6 \\
(0-16) \\
0 \cdot 142\end{array}$ & $\begin{array}{l}6 \cdot 5 \\
(0-17) \\
0 \cdot 116\end{array}$ & $\begin{array}{l}8 \cdot 5 \\
(2-11) \\
0 \cdot 068\end{array}$ \\
\hline$\underset{(\mathrm{mmHg})}{\text { Grip }}$ & $\begin{array}{l}79 \cdot 5 \\
(61-136)\end{array}$ & $\begin{array}{l}104 \\
(70-135) \\
0 \cdot 046\end{array}$ & $\begin{array}{l}106 \\
(96-126) \\
0 \cdot 046\end{array}$ & $\begin{array}{l}125 \\
(99-130) \\
0 \cdot 080\end{array}$ \\
\hline $\begin{array}{c}\text { Morning stiff- } \\
\text { ness (h) } \\
\text { p }\end{array}$ & $\begin{array}{l}1 \cdot 25 \\
(0 \cdot 50-24)\end{array}$ & $\begin{array}{l}0 \cdot 60 \\
(0-3) \\
0 \cdot 173\end{array}$ & $\begin{array}{l}0 \cdot 25 \\
(0-1) \\
0 \cdot 028\end{array}$ & $\begin{array}{l}0 \cdot 5 \\
(0-1) \\
0 \cdot 068\end{array}$ \\
\hline $\mathrm{Hb}(\mathrm{g} / \mathrm{dl})^{*}$ & $\begin{array}{l}10 \cdot 1 \\
(9 \cdot 1-13 \cdot 4)\end{array}$ & $\begin{array}{l}12 \cdot 2 \\
(10 \cdot 1-14 \cdot 3) \\
0 \cdot 028\end{array}$ & $\begin{array}{l}13 \cdot 5 \\
(10 \cdot 1-14 \cdot 2) \\
0 \cdot 043\end{array}$ & $\begin{array}{l}12 \cdot 9 \\
(10 \cdot 4-14) \\
0 \cdot 018\end{array}$ \\
\hline $\begin{array}{c}\text { ESR } \\
\qquad \begin{array}{c}\text { (mm/1st h) } \\
\text { p }\end{array}\end{array}$ & $\begin{array}{l}80 \cdot 5 \\
(28-127)\end{array}$ & $\begin{array}{l}35 \\
(7-82) \\
0.018\end{array}$ & $\begin{array}{l}23 \\
(7-85) \\
0.018\end{array}$ & $\begin{array}{l}25 \cdot 5 \\
(5-81) \\
0 \cdot 012\end{array}$ \\
\hline $\begin{array}{c}\text { Platelets } \times \\
10^{-9} / 1\end{array}$ & $\begin{array}{l}373 \\
(294-523)\end{array}$ & $\begin{array}{l}312 \\
(211-355) \\
0 \cdot 063\end{array}$ & $\begin{array}{l}278 \\
(235-395) \\
0 \cdot 063\end{array}$ & $\begin{array}{l}265 \\
(239-392) \\
0 \cdot 063\end{array}$ \\
\hline
\end{tabular}

*SI conversion: $\mathrm{g} / \mathrm{dl} \times 10=\mathrm{g} / \mathrm{l}$. 


\section{References}

1 Heuer MA, Pietrusko RG, Morris RW, Scheffler BJ. An analysis of worldwide safety experience with auranofin. $J$ Rheumatol 1985; 12: 695-9.

2 Ward JR, Williams J, Egger MJ, et al. Comparison of auranofin, gold sodium thiomalate, and placebo in the treatment of rheumatoid arthritis. Arthritis Rheum 1983; 26: 1303-15.

3 Lewis D, Capell HA. Is auranofin preferable to gold sodium thiomalate in the management of rheumatoid arthritis. In: Capell HA, Cole DS, Manghani KK, Morris RW, eds. Auranofin-current clinical practice. Series 7. Oxford: Excerpta Medica, 1982; 147-54.

4 Lewis D, Capell HA. Oral gold: a comparison with placebo and with intramuscular sodium aurothiomalate. Clin Rheumatol 1984; 3 (suppl 1): 83-96.
5 Ropes HW, Bennett GA, Gobb S, Jacob R, Jesser RA. Diagnostic criteria for rheumatoid arthritis. Ann Rheum Dis 1959; 18: 49-53.

6 Pullar T, Hunter JA, Capell HA. Does second line therapy affect the radiological progression of rheumatoid arthritis? Ann Rheum Dis 1984; 43: 18-23.

7 Seigel S. Non-parametric statistics for the behavioural sciences. New York: McGraw-Hill, 1956.

8 Mallya RK, Mace BEW. The assessment of disease activity in rheumatoid arthritis using a multivariate analysis. Rheumatol Rehabil 1981; 20: 14-7.

9 Gofton JP, O'Brien WM, Hurley JM, Scheffler BJ. Radiographic evaluation of erosion in rheumatoid arthritis; doubleblind study of auranofin versus placebo. $J$ Rheumatol 1984; 11 : 768-71. 